\title{
DUKUNGAN PEMERINTAH DAN STRATEGI KEBERLANJUTAN BISNIS UKM KOREA SELATAN DI TENGAH PANDEMI COVID 19
}

\author{
Ratnaningsih Hidayati', Nadya Megawati Rachman ${ }^{2}$ \\ ${ }^{1,2}$ Pusat Pendidikan dan Pelatihan Perdagangan Kementerian Perdagangan, Depok, Indonesia \\ ratna.hidayati@kemendag.go.id ${ }^{1}$, nadya.megawati@kemendag.go.id ${ }^{2}$
}

\begin{abstract}
Abstract Global pandemic of COVID-19 has bee creating economic disruption in many countries including South Korea. The decline in the trade sector due to the COVID-19 pandemic does not only affect large-scale industries. The Small and Medium Enterprises sector is also affected by the impact of the implementation of various policies in place to anticipate the spread of this virus. This study aims to provide an overview of government policies and business strategies for South Korean SMEs in the midst of the COVID-19 Pandemic and this study is also expected to provide input for the Government to design appropriate, fast and quality economic recovery programs for SMEs affected by COVID-19. . This paper uses a qualitative approach. The data collection technique was carried out through literature study / literature study and interviews with the Republic of Indonesia Trade Representative in South Korea. The results showed that as a country that was first affected by COVID-19, the response of the South Korean government was relatively fast and sufficient to guarantee business continuity for SMEs, there are five main policies implemented by the South Korean Government and five Business Strategies of SMEs in dealing with COVID- 19.
\end{abstract}

Keywords: covid-19, business, SMES, policy, strategy

\begin{abstract}
Abstrak
Abstrak Pandemi global COVID-19 telah menimbulkan gangguan ekonomi di banyak negara termasuk Korea Selatan. Penurunan sektor perdagangan akibat pandemi COVID-19 tidak hanya berdampak pada industri skala besar. Sektor Usaha Kecil dan Menengah juga terkena imbas dari penerapan berbagai kebijakan untuk mengantisipasi penyebaran virus ini. Kajian ini bertujuan untuk memberikan gambaran kebijakan pemerintah dan strategi bisnis bagi UKM Korsel di tengah Pandemi COVID-19 dan studi ini juga diharapkan dapat memberikan masukan bagi Pemerintah untuk merancang program pemulihan ekonomi yang tepat, cepat dan berkualitas bagi UKM. terkena COVID-19. . Makalah ini menggunakan pendekatan kualitatif. Teknik pengumpulan data dilakukan melalui studi pustaka / studi pustaka dan wawancara dengan Perwakilan Dagang Republik Indonesia di Korea Selatan. Hasil penelitian menunjukkan bahwa sebagai negara yang pertama kali terkena COVID-19, respon pemerintah Korea Selatan relatif cepat dan cukup untuk menjamin kelangsungan usaha bagi UKM, terdapat lima kebijakan utama yang diterapkan oleh Pemerintah Korea Selatan dan lima Strategi Bisnis. UKM dalam menangani COVID-19.
\end{abstract}

Kata kunci : covid-19, bisnis, UKM, kebijakan, strategi

Corresponding author : ratna.hidayati@kemendag.go.id

History of article: Received: September 2020, Revised: November 2020, Published: Januari 2021 


\section{PENDAHULUAN}

COVID-19 disebabkan oleh virus corona yang menyerang sistem pernafasan. Virus ini pertama kali muncul di Provinsi Wuhan China pada sekitar bulan Desember 2019. Kemudian kasus penularan virus ini berkembang sangat cepat bahkan ke berbagai negara, dan saat ini sudah merupakan suatu pandemi, melanda seluruh dunia. Pandemi COVID-19 telah memberikan dampak yang luar biasa pada perekonomian dunia, bahkan telah mengubah tatanan kehidupan di masa sebelum tahun 2020.

Berbagai kebijakan di bidang ekonomi telah dikeluarkan oleh pemerintah di seluruh dunia untuk mensikapi pandemi COVID-19. Akan tetapi sampai saat ini belum ada formula kebijakan tunggal yang efektif untuk dapat diterapkan oleh mayoritas negara-negara di dunia, karena permasalahan Kesehatan ini erat kaitannya dengan kebiasaan hidup dan tatanan sosial dalam masyarakat.

Pandemi yang berawal dari China telah meruntuhkan Sebagian besar sendi-sendi perekonomian di berbagai negara. Saat ini pengaruh China dalam perdagangan dunia sangat besar. Sebagai salah satu pusat industri dunia, China menjadi mitra dagang yang strategis untuk hampir seluruh negara di dunia, termasuk Indonesia. Menurut Ekonom Institute of Development Economics and Finance (Indef), Bhima Yudistira Adhinegara yang dikutip oleh (Astuti, 2020), Pandemi COVID19 ini berdampak terhadap laju pertumbuhan ekonomi Indonesia. Hal ini dapat ditelusuri dari korelasi hubungan ekonomi China dan Indonesia. Adanya korelasi yang sangat besar dalam perdagangan dan investasi antara Indonesia dan China berakibat terhadap penurunan pertumbuhan ekonomi. Artinya penurunan pertumbuhan di China mempengaruhi penurunan ekonomi di Indonesia, bisa dikatakan setiap 1\% penurunan pertumbuhan ekonomi China, ekonomi Indonesia bisa terpengaruh $0,3 \%$. Indef memproyeksikan pertumbuhan ekonomi China hanya sekitar $5 \%$ pada 2020 , atau turun $1 \%$ dibanding 2019. Berdasarkan data dari Bank Dunia, Pertumbuhan ekonomi China di kuartal kedua tahun 2020 adalah sebesar $3.2 \%$ setelah sebelumnya pada kuartal pertama sempat turun hingga minus $6.8 \%$.

Lesunya sektor perdagangan karena pandemi COVID-19 ini tidak hanya berpengaruh pada industri-industri skala besar. Sektor Usaha Kecil Menengah juga terkena oleh imbas diterapkannya berbagai kebijakan yang diberlakukan untuk melakukan antisipasi penyebaran virus ini supaya tidak meluas area penularannya. Kebijakan Lockdown di berbagai negara telah membatasi ruang gerak masyarakat sehingga banyak UKM yang belum mampu menyesuaikan dengan kondisi saat ini dan menutup usaha sementara waktu, dan lebih jauh lagi menghadapi kendala arus kas, termasuk juga UKM di negara Korea Selatan.

Penulisan kajian ilmiah ini bertujuan untuk memberikan gambaran mengenai kebijakan pemerintah dan strategi bisnis UKM Korea Selatan di tengah Pandemi COVID-19 sehingga dapat dijadikan sebagai bahan untuk melakukan patok banding (benchmark) bagi para pengusaha UKM Indonesia agar dapat bertahan ditengah lesunya roda perekonomian akibat pandemic COVID 19. Selain itu, kajian ini juga diharapkan dapat memberikan masukan bagi Pemerintah khususnya yang memiliki tugas dan fungsi melakukan pembinaan terhadap pengusaha Usaha Kecil dan Menengah untuk merancang programprogram pemulihan ekonomi bagi UKM terdampak COVID-19 yang cepat dilaksanakan, berkualitas dan tepat sasaran.

\section{KAJIAN PUSTAKA}

Perekonomian Korea sangat terkait dengan gangguan dalam perdagangan internasional dan rantai nilai global. Korea adalah negara yang berorientasi perdagangan dan sangat bergantung pada ekspor. China adalah mitra dagang terbesarnya baik dalam hal ekspor maupun impor. Secara khusus, Korea 
adalah negara eksportir terbesar ke-5 di dunia, dengan China menyumbang lebih dari $25 \%$ pangsa pasar ekspornya. Banyak industri di Korea mengekspor barang setengah jadi (kebanyakan produk berteknologi tinggi) ke China, di mana kemudian dirakit menjadi produk jadi dan dikirim ke konsumen akhir mereka di seluruh dunia. Saat ini pandemi global telah mengurangi permintaan di negaratujuan akhir (misalnya, dari Amerika Serikat dan Eropa). (Liu et al., 2020)

Resesi ekonomi yang dialami oleh Korea selatan antara lain juga disebabkan oleh kontraksi pembelanjaan rumah tangga domestik. (Ho et al., 2020) menyatakan bahwa pengeluaran rumah tangga menyumbang hampir setengah dari PDB Korea Selatan, yang merupakan bagian penting dari permintaan agregat di dalam negeri. Seperti negara lain di seluruh dunia, pandemi ini telah berdampak pada pengeluaran rumah tangga. Penutupan bisnis dan tindakan tegas menjaga jarak yang diberlakukan oleh pemerintah telah secara langsung menyebabkan penurunan tajam dalam pekerjaan dan pengeluaran rumah tangga di sebagian besar wilayahnegara. Meskipun Korea sampai saat ini berhasil menghindari penutupan total (total lockdown), namun negara ini juga menghadapi kontraksi tajam dalam pengeluaran rumah tangga, karena banyak konsumen memperkirakan pendapatan dan tabungan mereka menurun karena adanya ketidakpastian akibat pandemi.

\section{METODE PENELITIAN}

Penulisan makalah ini menggunakan pendekatan kualitatif. Teknik pengumpulan data dilakukan melalui wawancara dengan narasumber yaitu Perwakilan Perdagangan Republik Indonesia di Korea Selatan dan studi literatur/studi kepustakaan.

\section{HASIL DAN PEMBAHASAN}

Korea Selatan merupakan salah satu negara maju dengan perkiraan Pendapatan Domestik Bruto di tahun 2019 sebesar USD
1.629.593 juta. Saat ini kondisi ekonomi di Korea Selatan tengah mengalami penurunan, bahkan menyatakan sedang memasuki masa resesi ekonomi.

Pada tahap awal wabah COVID-19, Korea menghadapi krisis besar. Korea adalah negara terbesar kedua dalam hal jumlah kasus yang terkonfirmasi positif. Hal ini disebabkan karena kedekatan lokasi geografisnya dengan China dan penyebab lainnya adalah karena infeksi komunitas berskala besar. Namun, Korea berhasil memperlambat penyebaran dan melakukan upaya terbaik untuk mencegah gelombang kedua infeksi. Korea juga secara proaktif mendorong inisiatif yang bertujuan untuk mengubah krisis ini menjadi sebuah peluang. Dalam upaya memerangi virus, pemerintah dan bisnis Korea mengembangkan berbagai tindakan pencegahan inovatif (misalnya, drive-through testing) dan produk inovatif untuk pengujian berupa testing kit. yang dapat digunakan di seluruh dunia.

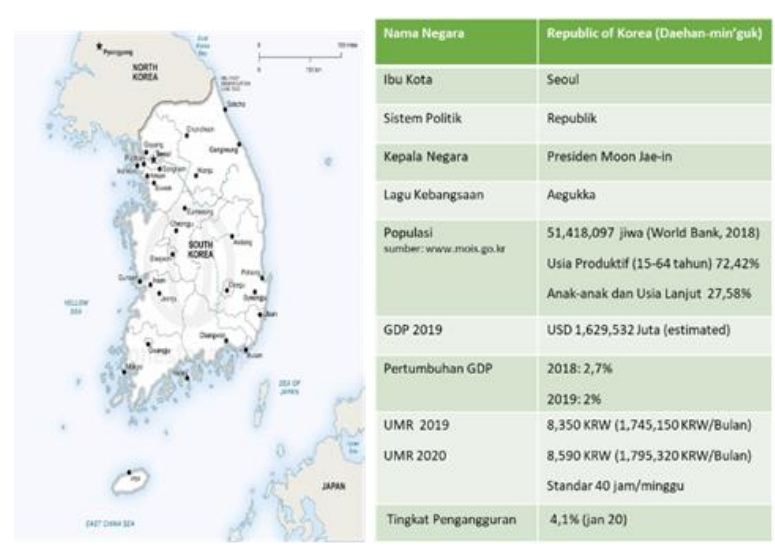

Gambar 1. Profil Negara Korea Selatan

Sumber data: Korea National Statistic, (diolah 2020)

\section{Gambaran UKM Korea Selatan}

Berdasarkan data yang dihimpun dari Korea National Statistics, jumlah UKM di Korea Selatan mencapai 3.733.000 dengan jumlah pekerja 15.528.000 yang tersebar diseluruh wilayah Korea Selatan. Data mengenai jumlah UKM dan data jumlah pekerja UKM di Korea Selatan disajikan pada Gambar 2. 


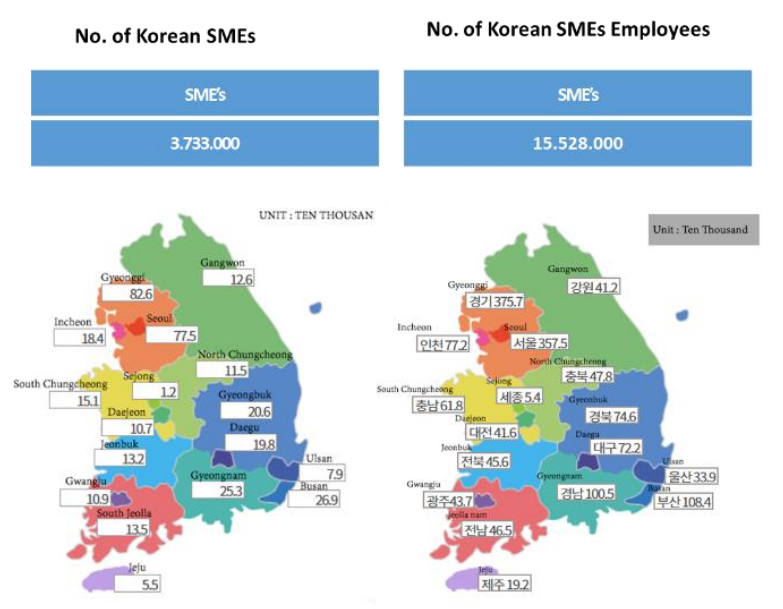

Gambar 2. Peta penyebaran dan Jumlah UKM serta Pekerja UKM di Korea Selatan

Sumber : Korea National Statistics, (diolah 2020)

Sama halnya dengan Indonesia, UKM juga merupakan tulang punggung bagi perekonomian Korea Selatan. Berdasarkan data yang diperoleh dari The Ministry of SMEs and Startup Korea Selatan, jumlah UKM di Korea Selatan mencapai $99.9 \%$ dari jumlah perusahaan di Korea Selatan dan menyerap 87.9\% angkatan kerja di Korea Selatan serta kontribusi UKM terhadap ekspor yang berasal dari Korea Selatan sebesar 37.5\%. Selain itu, jumlah penyerapan tenaga kerja pada jenis usaha mikro di Korea Selatan adalah sebanyak $38 \%$ (6.5 juta orang), usaha kecil adalah sebanyak 25\% (3.96 juta orang), usaha menengah sebanyak $25 \%$ (4.01 juta orang) dan untuk perusahaan besar adalah sebanyak $12 \%$ (1.94 juta orang). Sementara itu, nilai tambah yang dihasilkan oleh UKM juga lebih tinggi daripada perusahaan besar yaitu mencapai $51.2 \%$.

Sebagian besar UKM di Korea Selatan adalah UKM dalam bidang manufaktur. UKM di Korea Selatan ini menjadi pemasok bagi perusahaan-perusahaan besar di Korea Selatan, seperti Samsung, Hyundai dan LG. Berdasarkan penelitian yang dilakukan oleh Korean Business Federation of SME's yang melakukan survei terhadap 250 UKM di Korea Selatan saat pandemi COVID-19 berlangsung,
34.4\% menyatakan bahwa UKM tersebut merasakan dampak langsung yang signifikan. Permasalahan yang dialami oleh UKM yang terkena dampak langsung dari pandemi COVID-19 adalah kekurangan raw material (bahan baku) pada unit produksi yang pasokannya sebagian besar berasal dari China. Selain Amerika Serikat, China merupakan mitra dagang terbesar bagi Korea Selatan. Selain itu 37.9\% UKM yang merasakan dampak COVID-19 yang signifikan adalah sektor jasa, yang disebabkan oleh penurunan wisatawan yang datang ke Korea Selatan. UKM dalam bidang makanan dan minuman juga merupakan sektor usaha yang terkena dampak COVID-19 secara langsung yang disebabkan oleh perubahan gaya hidup dengan diberlakukannya social dan physical distancing.

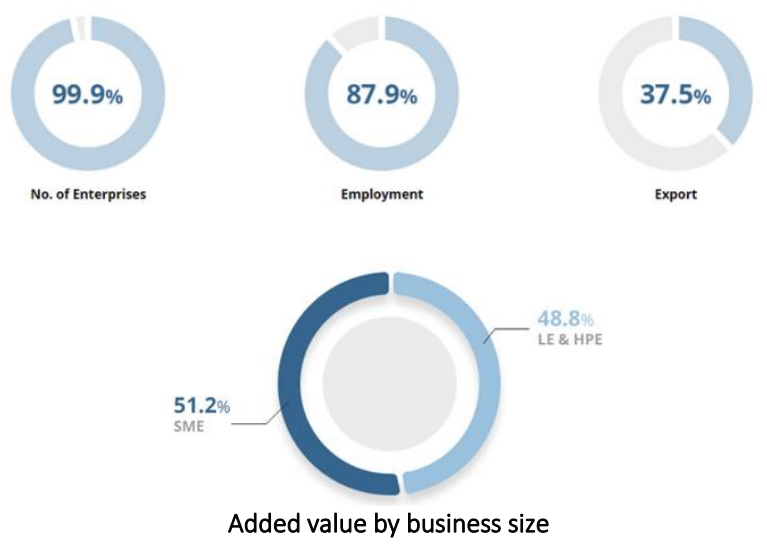

Gambar 3. Profil Sektor Usaha dan Penyerapan Tenaga Kerja UKM di Korea Selatan

Sumber : The Ministry of SMEs and Startups (MSS) South Korea

\section{Kebijakan Pemerintah Korea Selatan untuk UKM Selama Masa Pandemi Covid-19}

Respon pemerintah Korea Selatan terhadap dampak kelesuan ekonomi yang disebabkan oleh COVID-19 merupakan kebijakan yang bersifat multidimensi (B. Lee, 2020). Beberapa kebijakan tersebut diantaranya adalah:

1. Pengurangan dan penangguhan biaya operasional. 
Sejumlah tindakan telah dilakukan di area ini. Misalnya, pemerintah menurunkan harga sewa sebesar $25 \%$ selama enam bulan untuk UKM yang beroperasi di fasilitas komersial dan bandara. Korporasi Asuransi Perdagangan Korea menurunkan biaya untuk asuransi UKM berorientasi ekspor hingga $50 \%$ di seluruh negeri. Antara lain, perusahaan pengekspor yang berlokasi di Zona Khusus Bencana COVID-19, yaitu di provinsi tenggara yang memiliki persentase jumlah pasien yang relatif banyak dari seluruh populasi penduduk negeri itu. UKM berorientasi ekpor ini mendapat manfaat dari pembebasan premi asuransi ekspor selama enam bulan.

Beban pajak pada bisnis yang harus tutup karena seorang pelanggan dinyatakan positif terkena virus corona juga berkurang. Misalnya, terdapat pemberitahuan pengenaan dan pemungutan pajak daerah yang ditunda selama enam bulan, dengan kemungkinan perpanjangan selama enam bulan, selain itu juga Pemerintah memberikan kelonggaran yang memungkinkan para pengusaha UKM untuk mlakukan pembayaran pajak tersebut dengan mencicil. Pajak perusahaan dan PPN juga telah ditunda untuk Sembilan bulan. Pada saat yang sama, pemerintah daerah telah menyiapkan langkah tambahan terpisah untuk mendukung bisnis di wilayah yurisdiksi mereka. Sejalan dengan itu, sektor keuangan akan mendukung pemulihan UKM dengan memperpanjang jatuh tempo pinjaman setidaknya enam bulan dan dengan menawarkan enam bulan masa tenggang pembayaran bunga.

2. Paket dukungan finansial untuk meningkatkan likuiditas.

Pemerintah Korea Selatan bekerja sama dengan bank sentral, bank pembangunan milik negara dan seluruh sektor keuangan untuk memberikan dukungan sumber daya tambahan untuk UKM yang menghadapi kesulitan keuangan karena terdampak oleh pandemi. Sebanyak 41,8 triliun won (US \$ 35,0 miliar, atau 2,1 persen dari PDB) digulirkan oleh pemerintah untuk membantu menstabilkan pasar keuangan sekaligus memasok likuiditas untuk UKM. UKM diberikan pinjaman cepat melalui Korea Credit Guarantee Fund dan Korea Technology Finance Corporation. Pemerintah menawarkan dana dengan bunga sangat rendah kepada UKM dan diberikan jaminan penuh dan khusus. Selain itu, jaminan darurat penuh diberikan kepada usaha kecil dengan penjualan tahunan kurang dari 100 juta won (US \$ 84.000) yang secara langsung atau tidak langsung terdampak oleh pandemi.

3. Insentif pajak untuk meningkatkan permintaan.

Pemerintah melakukan kampanye untuk mempromosikan metode pembayaran prabayar dan pra-pembelian di sektor swasta Pemerintah juga menawarkan pengurangan pajak penghasilan sebesar 80 persen untuk pengguna kartu kredit dan kartu debit, untuk periode empat bulan pada periode April hingga Juli 2020 sehingga diharapkan permintaan masyarakat terhadap barang dan jasa akan meningkat.

4. Program dukungan fiskal untuk mempertahankan lapangan kerja.

Pemerintah memberikan dukungan untuk retensi karyawan dan memperkenalkan langkah-langkah untuk menyelesaikan kesulitan yang dihadapi oleh pemberi kerja dan pekerja. Hal ini dirancang untuk membantu bisnis mempertahankan daya saing dan pekerja terampil mereka sehingga pasar tenaga kerja dapat pulih dengan cepat setelah krisis berakhir. Contoh dari program dukungan fiscal untuk lapangan kerja ini adalah kenaikan dalam pendanaan untuk Program Job 
Stability Funds, yang mensubsidi sebagian dari gaji karyawan, dan introduksi program Emergency Employment Stability Subsidy. Melalui program ini pemerintah memberikan 500.000 won (US \$ 420) sebulan selama tiga bulan untuk karyawan yang harus mengambil cuti tidak dibayar dari UKM.

5. Prosedur administrasi yang efisien dan dipercepat.

Prosedur jalur cepat diterapkan untuk kontrak pengadaan publik. Pemerintah merampingkan prosedur bea cukai menjadi 24 jam sehari untuk mempromosikan kegiatan ekspor dan impor. Pemerintah juga memberlakukan sistem bea cukai yang sederhana untuk mengimpor bahan mentah dan barang setengah jadi untuk membantu produsen dalam negeri mempertahankan operasi normalnya. Selain itu, pemerintah meningkatkan pagu kontrak swasta untuk usaha kecil yang dapat ditandatangani tanpa prosedur tender. Masa pemeriksaan dan pendaftaran dipersingkat dari 12 menjadi 8 minggu. Pemerintah akan mengurangi simpanan lelang untuk pembelian publik dan konstruksi pemerintah sebesar 50 persen, menurunkan beban perusahaan yang melalui proses pengadaan. Layanan Bea Cukai Korea diharapkan untuk menunda penyelidikan bea cukai untuk perusahaan yang mempertahankan karyawannya, dan untuk UKM dengan kegiatan ekspor/impor. Bank Ekspor dan Impor Korea (KEXIM) memperkenalkan program pinjaman dipercepat dengan total 200 miliar won (US \$ 167,4 juta) untuk UKM ekspor-impor yang tidak memiliki riwayat transaksi atau peringkat kredit dengan KEXIM. Biasanya UKM ini memerlukan evaluasi kualitatif, yang dapat memakan waktu lama, tetapi dalam periode krisis UKM cukup menyediakan laporan keuangan saja.

\section{Strategi Bisnis UKM Korea Selatan}

Salah satu penentu sukses terbesar bagi UKM adalah dengan memperhatikan dengan seksama kebutuhan serta harapan dari pelanggan. Disaat terjadi perubahan drastis yang disebabkan oleh pandemi ini, banyak model bisnis atau usaha yang tidak mampu bertahan, tetapi peluang baru akan tercipta(Venkatesh, 2020). Dalam kondisi ini, dapat dimaklumi jika UKM merasa sangat sulit untuk fokus pada identifikasi dan eksplorasi peluang baru dengan kondisi hilangnya keuntungan, pelanggan bahkan karyawan kunci. Namun, dengan kelangsungan hidup UKM sebagai taruhannya, sangat penting bagi pemilik untuk melatih ketahanan dan mengadopsi pola pikir untuk mengenali dan mengidentifikasi peluang untuk bangkit dan bergerak maju. Berikut strategi bisnis yang dijalankan oleh UKM di Korea Selatan dalam menghadapi pandemi COVID-19 :

1. Efisiensi dalam semua lini proses bisnis.

Peningkatan efisiensi dapat dilakukan melalui Strategi penurunan biaya. Hal ini akan lebih efektif untuk diterapkan jika terdapat standarisasi aktivitas rantai nilai seperti desain, sumber, manufaktur, dan ritel alih-alih merancang produk untuk memenuhi pasar khusus tertentu. Oleh karena itu, dalam banyak kasus, UKM Korea Selatan berhasil menerapkan strategi kepemimpinan biaya ini dengan memperluas volume mereka melalui internasionalisasi di pasar luar negeri (I. H. Lee \& Marvel, 2009).

2. Konsisten dalam menerapkan Standard Operational Procedure (SOP) yang telah dibuat.

Budaya pali pali atau cepat-cepat dalam Bahasa Indonesia, menyebabkan UKM di Korea Selatan harus membuat SOP bagi setiap proses bisnis yang mereka jalankan, hal ini bertujuan supaya proses bisnis berjalan dengan efektif dan efisien. Selain proses yang dilewati harus dijalankan secara cepat,SOP juga harus dijalankan secara tepat. Pekerja di Korea Selatan dikenal 
patuh terhadap prosedur yang telah ditetapkan, hal ini juga bertujuan untuk menjaga kualitas serta mempertahankan pelanggan yang ada.

3. Pemanfaatan Teknologi Informasi

UKM di Korea Selatan sangat terbiasa dengan penggunaan teknologi informasi dalam melakukan bisnis mereka. Penggunaan teknologi informasi membantu UKM untuk dapat selalu terhubung dengan pelanggan dalam masa pandemi(Papadopoulos et al., 2020). (Jeon et al., 2006) dalam penelitiannya menyatakan bahwa terdapat beberapa faktor yang berpengaruh terhadap adopsi $e$ business di Korea Selatan, yaitu tingkat pengetahuan CEO tentang e-business; keuntungan relatif dari penerapan $e$ business; dukungan dari pemerintah; bagian dari strategi globalisasi dan faktor pengaruh dari hubungan dengan Korea Utara. Saluran bisnis digital memberikan peluang unik untuk menyegarkan kembali dan mencari kesesuaian produk dengan pasar, serta perburuan model bisnis baru yang mampu bertahan dan berkembang ketika terdampak COVID-19 di dunia (Liguori \& Pittz, 2020). Salah satu bentuk contoh pemanfaatan teknologi informasi oleh UKM yang diterapkan di Korea Selatan yaitu penggunaan aplikasi online terintegrasi untuk pesan-antar makanan (delivery order). Aplikasi untuk delivery order yang biasa digunakan di Korea Selatan diantaranya adalah Yogiyo, Baedal Minjok, dan Baedal Tong, mirip seperti Go Food di Indonesia. Baedal merupakan Bahasa Korea untuk istilah delivery. Perbedaannya proses pengantarannya dilakukan oleh masingmasing restoran. Dalam satu aplikasi, ada berbagai pilihan kategori makanan dan ratusan restoran yang dapat dipilih. Untuk pengantaran yang dilakukan oleh pengemudi eksternal (seperti Go Food) baru diperkenalkan tahun 2017 oleh Baedal Minjok, di mana pelanggan bisa memesan dari restoran yang umumnya tidak menyediakan jasa delivery (seperti sushi atau cafe). Penggunaan aplikasi ini ditujukan untuk meningkatkan kemudahan bagi pelanggan untuk memesan makanan dalam situasi pandemi. Selain itu, UKM di Korea Selatan memanfaatkan sosial media sebagai media promosi serta media untuk memantau perubahan tren, dengan memperhatikan jumlah likes atau tayangan serta komentar atau testimoni dari penggunaan suatu produk/jasa pada sosial media.

\section{Strategic Agility}

Strategic Agility adalah kemampuan perusahaan untuk merespon dengan cepat kondisi lingkungan yang berubah (Gerald et al., 2020). Fleksibilitas dalam respons operasional perusahaan terhadap diskontinuitas dan volatilitas dalam bisnis lingkungan mendefinisikan Strategic Agility suatu perusahaan. Perusahaan yang memiliki kemampuan Strategic Agility dapat berhasil memprediksi dan beradaptasi dengan peluang dan ancaman baru. Sejalan dengan hal tersebut, Mavengere (2013) mengemukakan bahwa Strategic Agility berkaitan dengan kepekaan organisasi atau dipersenjatai dengan pandangan ke depan untuk memahami dan memprediksi kejadian baru di lingkungan tempat organisasi beroperasi. Ini adalah kemampuan tegas untuk mengidentifikasi dan bereaksi terhadap peluang dan ancaman lingkungan dengan kemakmuran, kecepatan, dan kegesitan (Tallon \& Pinsonneault, 2011). Shin et al., (2015) dalam penelitiannya tentang Pengaruh Strategic Agility terhadap kinerja dan operasi perusahaan menyatakan bahwa kelincahan strategis menunjukkan efek langsung dan juga efek tidak langsung (mediasi) yang lebih kuat melalui daya tanggap operasional terhadap retensi pelanggan. Sebaliknya, ketangkasan strategis tidak mempengaruhi kinerja keuangan baik secara langsung maupun 
tidak langsung melalui daya tanggap operasional. Yun et al., (2015) menyatakan bahwa UKM tidak dapat bertahan jika mereka tidak menerima inovasi terbuka dalam strategi pengetahuan dan model bisnis. UKM yang menunjukkan keterbatasan mutlak dalam sumber daya dan tenaga kerja harus benar-benar menerapkan strategi inovasi terbuka untuk mengamankan sumber daya yang lebih beragam dari pasar dan basis pengetahuan eksternal daripada mempersiapkan semua sumber daya dan kemampuan sendiri.

5. Pelayanan prima untuk pelanggan

Menjaga hubungan dengan pelanggan yang ada saat ini sangat penting, dan berkomunikasi secara efektif dengan pelanggan adalah kunci untuk membangun kepercayaan (Liguori \& Pittz, 2020). Pemilik UKM di Korea Selatan memanfaatkan situs web dan saluran media sosial mereka untuk mengomunikasikan setiap perubahan dalam operasi bisnis (misalnya, mengubah jam buka toko atau perubahan layanan lainnya). Cara jitu untuk memenangkan hati pelanggan di Korea Selatan adalah dengan menggunakan sistem poin. Pelanggan cenderung loyal pada satu produk saja karena sistem poin yang berlaku.

Biasanya aplikasi delivery memberikan $1-2 \%$ poin dari setiap nilai pembelian. Terlihat sedikit, tetapi karena intensitas penggunaan aplikasi dengan frekuensi yang tinggi, pelanggan dapat menikmati potongan harga/cashback bahkan mendapatkan produk secara gratis. Terdapat juga sistem promosi kreatif lainnya, seperti tambahan poin jika pelanggan menulis review. Pemilik toko juga dapat membalas review pelanggan secara langsung. Meskipun ada realitas ekonomi yang diperlukan untuk mempertahankan penjualan dan pendapatan, pandemi saat ini adalah peluang untuk membantu memperdalam hubungan dengan pelanggan.

\section{KESIMPULAN DAN SARAN}

Sebagai negara yang pertama kali terdampak oleh COVID-19, respon pemerintah Korea Selatan relatif cepat dan cukup memberikan jaminan keberlangsungan bisnis bagi UKM. Beberapa kebijakan itu adalah (1) Pengurangan dan penangguhan biaya operasional; (2) Paket dukungan finansial untuk meningkatkan likuiditas; (3) Insentif pajak untuk meningkatkan permintaan; (4) Program dukungan fiskal untuk mempertahankan lapangan kerja; (5) Prosedur administrasi yang efisien dan dipercepat.

Walaupun saat ini Korea Selatan tengah mengalami masa resesi, kondisi UKM di Korea Selatan cukup dapat bertahan dari krisis. Strategi bisnis yang diterapkan oleh pengusaha UKM di Korea Selatan ini adalah: (1) Efisiensi dalam semua lini proses bisnis; (2) Konsisten dengan SOP; (3) Pemanfaatan teknologi informasi; (4) Strategic agility; dan (5) Pelayanan yang prima untuk pelanggan.

\section{DAFTAR PUSTAKA}

Astuti, D. S. P. (2020). Ekonomi di Masa Pandemi Covid-19. Suara Merdeka.

Gerald, E., Obianuju, A., \& Chukwunonso, N. (2020). Strategic agility and performance of small and medium enterprises in the phase of Covid-19 pandemic. International Journal of Financial, Accounting, and Management, 2(1), 4150.

Ho, B. J., Kim, A., \& Yamakawa, N. (2020). Consumers remain resilient even as they expect an impending hit to their personal nances.

https://www.mckinsey.com/featuredinsights/asia-pacific/survey-asianconsumer-sentiment-during-the-covid19-crisis

Jeon, B. N., Han, K. S., \& Lee, M. J. (2006). Determining factors for the adoption of ebusiness: The case of SMEs in Korea. Applied Economics, 38(16), 1905-1916. 
https://doi.org/10.1080/00036840500427 262

Lee, B. (2020). Support for SMEs in the Covid19 crisis: the case of the Republic of Korea. https://www.ebrd.com/what-wedo/economic-research-and-data/cseeconomists/support-for-smes-in-covid19crisis-the-case-of-republic-of-korea.html

Lee, I. H., \& Marvel, M. R. (2009). The moderating effects of home region orientation on $\mathrm{R} \& \mathrm{D}$ investment and international SME performance: Lessons from Korea. European Management Journal, 27(5), 316-326. https://doi.org/10.1016/j.emj.2009.04.011

Liguori, E. W., \& Pittz, T. G. (2020). Strategies for small business: Surviving and thriving in the era of COVID-19. Journal of the International Council for Small Business, $1-5$.

Liu, Y., Lee, J. M., \& Lee, C. (2020). The challenges and opportunities of a global health crisis: the management and business implications of COVID-19 from an Asian perspective. Asian Business and Management.

https://doi.org/10.1057/s41291-02000119-x

Mavengere, N. (2013). Information systems role in strategic agility: A supply chain context.

Papadopoulos, T., Baltas, K. N., \& Balta, M. E. (2020). The use of digital technologies by small and medium enterprises during COVID-19: Implications for theory and practice. International Journal of Information Management, June, 102192. https://doi.org/10.1016/j.ijinfomgt.2020.1 02192

Shin, H., Lee, J. N., Kim, D., \& Rhim, H. (2015). Strategic agility of Korean small and medium enterprises and its influence on operational and firm performance. International Journal of Production Economics, 168, 181-196. https://doi.org/10.1016/j.ijpe.2015.06.015
Tallon, P., \& Pinsonneault, A. (2011). Competing Perspectives on the Link Between Strategic Information Technology Strategic Information Technology Alignment And Organizational Agility: Insights From A Mediation Model 1. May 2018. https://doi.org/10.2307/23044052

Venkatesh, V. (2020). Impacts of COVID-19: A research agenda to support people in their fight. International Journal of Information Management, 102197.

Yun, J. J., Jung, W., \& Yang, J. (2015). Knowledge strategy and business model conditions for sustainable growth of SMEs. Journal of Science \& Technology Policy ManagementManagement, 6(3), 246-262. 